\title{
Benthic microalgal production at Stellwagen Bank, Massachusetts Bay, USA
}

\author{
Lawrence B. Cahoon ${ }^{1}$, Guy R. Beretich Jr ${ }^{2}$, Carrie J. Thomas ${ }^{3}$, Amy M. McDonald ${ }^{4}$ \\ ${ }^{1}$ Department of Biological Sciences, UNC Wilmington, Wilmington, North Carolina 28403, USA \\ ${ }^{2}$ Department of Microbiology, Pathology, and Parasitology, College of Veterinary Medicine, North Carolina State \\ University, Raleigh, North Carolina 27606, USA \\ ${ }^{3}$ Department of Marine, Earth and Atmospheric Sciences, North Carolina State University, Raleigh, \\ North Carolina 27695-8208, USA \\ ${ }^{4}$ Department of Oceanography, Old Dominion University, 1054 W. 47th St., Norfolk, Virginia, 23529-0276, USA
}

\begin{abstract}
Benthic microalgal chlorophyll $a$ and production were measured at 3 sites at Stellwagen Bank, a cold temperate continental shelf habitat in Massachusetts Bay, USA, during August 1991. Benthic microalgal chlorophyll a averaged $39.8 \mathrm{mg} \mathrm{m}^{-2}$, vs average integrated phytoplankton chlorophyll $a$ of $25.9 \mathrm{mg} \mathrm{m}^{-2}$. Gross benthic microalgal production, measured by oxygen exchange in clear and opaque benthic chambers, averaged $20.9 \mathrm{mg} \mathrm{C} \mathrm{m}^{-2} \mathrm{~h}^{-1}$ This production was supported by average daily light fluxes to the bottom that never exceeded $1 \%$ of surface incident radiation and were as low as $4.7 \mu \mathrm{E} \mathrm{m}^{-2} \mathrm{~s}^{-1}$. These results indicate that benthic microalgal production can be spatially extensive and quantitatively important in continental shelf ecosystems.
\end{abstract}

KEY WORDS: Light $\cdot$ Microalgae $\cdot$ Phytoplankton $\cdot$ Production

\section{INTRODUCTION}

The biomass and productivity of benthic microalgae have been studied extensively in intertidal and estuarine habitats (e.g. Cadee \& Hegeman 1974, Colijn \& de Jonge 1984, Varela \& Penas 1985, Lukatelich \& McComb 1986). Comparatively few studies of benthic microalgal biomass and production in subtidal waters have been published, primarily from nearshore temperate and polar habitats (e.g. Matheke \& Horner 1974, Sundbäck \& Jönsson 1988, Herndl et al. 1989. Rivkin \& DeLaca 1990), and tropical reef habitats (e.g. Bunt et al. 1972, Sournia 1976). However, Cahoon et al. $(1990,1992)$ and Cahoon \& Cooke (1992) showed that productive benthic microalgae extend across the continental shelf into shallow slope habitats off North Carolina, USA, suggesting that benthic microalgae might be important in offshore habitats as well.

The light extinction properties of continental shelf waters frequently permit light fluxes $\geq 1 \%$ of incident radiation to reach the bottom, which predicts measurable benthic microalgal productivity at those times and places. However, the photosynthetic capabilities of benthic microalgae appear to enable them to sustain measurable production at photosynthetic photon flux densities (PPFD) approaching the $0.1 \%$ level (Palmisano et al. 1985, 1987, Rivkin \& DeLaca 1990).

Light extinction data (calculated from Secchi depths) from 17879 oceanographic stations with total depth $\leq 200 \mathrm{~m}$ showed that $\geq 1 \%$ of surface incident radiation would reach the bottom at 2653 of those stations and $\geq 0.1 \%$ at an additional 2772 stations (NODC 1987). If these data are representative, then up to $30 \%$ of continental shelf waters may support some benthic microalgal production. However, few field data exist with which to test this hypothesis properly. Benthic microalgal production measured by Cahoon \& Cooke (1992) was supported by PPFD levels $\geq 1 \%$ incident in clear, oligotrophic waters. Palmisano et al. (1985) did not report production data, and Palmisano et al. (1987) studied photosynthesis-irradiance relationships in the laboratory. Both these studies and that of Rivkin \& DeLaca (1990) were conducted in the Antarctic, a highly seasonal, boreal ecosystem. 
In this study benthic microalgal chlorophyll a (chl a) and production were measured in a cold temperate continental shelf ecosystem, Stellwagen Bank, Massachusetts, USA, with high phytoplankton biomass and PPFD to the bottom $<1 \%$ surface incident radiation.

\section{METHODS AND MATERIALS}

Stellwagen Bank is a shallow ledge, defined by the $40 \mathrm{~m}$ isobath, composed of sand and gravel lying between Massachusetts Bay and the much larger and deeper Gulf of Maine (Fig. 1). Waters from Cape Cod Bay and Massachusetts Bay are carried over Stellwagen Bank by tidal currents and the prevailing counterclockwise surface circulation in the southern Gulf of Maine (Yentsch \& Garfield 1981). Deep cold water $\left(<8^{\circ} \mathrm{C}\right)$ from the Gulf of Maine is also advected over the Bank (C. Mayo pers. comm, L. Stewart pers. comm.), introducing nutrients to the euphotic zone there as elsewhere in the Gulf of Maine, and stimulating high phytoplankton production (Yentsch \& Garfield 1981, Holligan et al. 1984). Macroalgae grew on the Bank before trawling and dragging eliminated them (C. Mayo pers. comm.). Macroalgae are reported

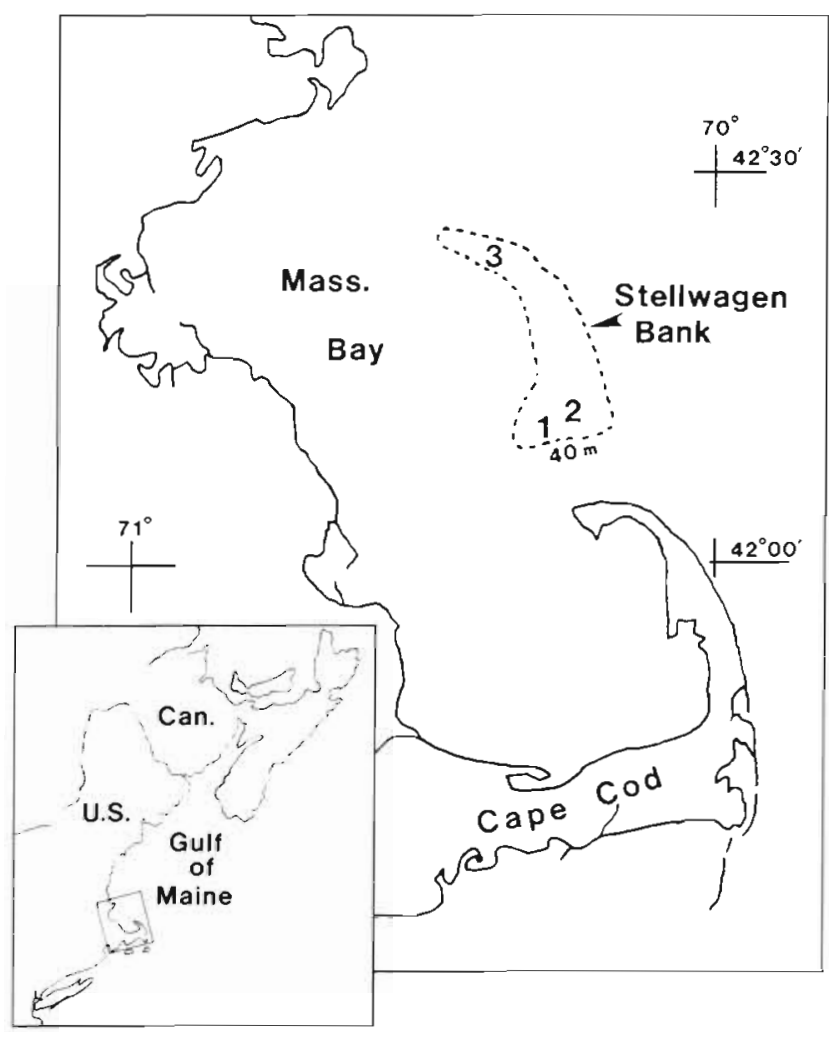

Fig. 1. Location of study sites at Stellwagen Bank, Massachusetts Bay. Depths at Site $1=21 \mathrm{~m}$, Site $2=28 \mathrm{~m}$, and Site $3=28 \mathrm{~m}$ growing at depths to $50 \mathrm{~m}$ elsewhere in New England waters (Vadas \& Steneck 1988). Chlorophyll a concentrations reported for Stellwagen Bank waters are approximately $1 \mathrm{\mu g} \mathrm{l}^{-1}$ (Holligan et al. 1984).

Benthic microalgal production was measured in situ at 3 sites on Stellwagen Bank in August 1991 (Fig. 1). Measurement of benthic microalgal production and associated benthic and near-bottom sampling were conducted by SCUBA divers. Benthic microalgal production was estimated by measuring changes in dissolved oxygen concentrations inside clear and opaque benthic chambers placed on the bottom by divers in the morning and retrieved in the afternoon. Previous results showed that a 6 to $8 \mathrm{~h}$ incubation was sufficient to yield measurable changes in dissolved oxygen concentrations inside the benthic chambers (Cahoon \& Cooke 1992).

The benthic chambers used in microalgal production determinations were made of clear plastic domes of $30 \mathrm{~cm}$ diameter. These domes transmitted approximately $85 \%$ of photosynthetically active radiation (PAR). Dark chambers were constructed by painting domes with $>4$ coats of flat black latex paint.

A typical microalgal production measurement was begun by placing 4 clear and 4 opaque chambers alternately on a sand bottom devoid of visible macrophytes. The domes were placed carefully to avoid disturbance of the sediment. Whirling cup rotors to stir the domes (Cahoon 1988) were attached and sealed with silicone sealant. Water samples for dissolved oxygen and nutrient analyses were withdrawn from each chamber with $50 \mathrm{ml}$ plastic syringes after slowly flushing the syringes 2 to 3 times to stir the chamber contents but without disturbing the sediments. Results of nutrient analyses will be reported elsewhere. Temperature $\left({ }^{\circ} \mathrm{C}\right)$ was measured with a hand-held thermometer at the beginning of each incubation. Typical incubations commenced at ca 09:00 $\mathrm{h}$ and were ended at ca 16:00 h, and ranged from 6.25 to $7.75 \mathrm{~h}$. Final sets of dissolved oxygen and nutrient samples were then taken.

Dissolved oxygen was measured by the Winkler technique (Strickland \& Parsons 1972). All samples were fixed on the sea bed immediately after withdrawal from the chambers. Winkler analyses were completed within $12 \mathrm{~h}$.

Net benthic primary production and respiration were calculated by measuring changes in dissolved oxygen concentrations in each clear or dark chamber, respectively, as by Cahoon \& Cooke (1992).

Gross benthic production for each field day's measurements was calculated by summing respiration and net production. Gross production is a better measure of microalgal growth than net production because chamber incubation measurements necessarily include the respiratory oxygen consumption of 
sediment-associated heterotrophs and chemical oxygen demand by sediments (Pamatmat 1968).

Sediment samples for analysis of benthic microalgal pigments were collected concurrently with initial placement of the chambers. Sets of 9 samples were taken with a $1 \mathrm{~cm}$ diameter hand-held coring tube to a depth $\geq 3 \mathrm{~cm}$ immediately adjacent to each benthic chamber. Sediment samples collected in this way were placed in $15 \mathrm{ml}$ plastic screw-cap tubes, capped, returned to the surface, allowed to settle for ca $1 \mathrm{~h}$ and the supernatant water decanted carefully. Sediment samples were then frozen at $-4{ }^{\circ} \mathrm{C}$ for later analysis.

Benthic microalgal biomass was estimated as $\mathrm{mg}$ chl $a \mathrm{~m}^{-2}$ on sets of 5 replicate samples from each dive site/day according to Whitney \& Darley (1979). This spectrophotometric method employs partitioning of a $90 \%$ acetone pigment extract with hexane to eliminate interference from degraded pigments that are common in sediment samples. Comparisons of this method with the standard fluorometric method (Parsons et al. 1984) showed that when degraded pigments were not important the 2 methods gave comparable results, but that degraded pigments were sometimes important in sediment samples (Beretich 1992).

Selected sediment samples from each study site were extracted in $90 \%$ acetone and analyzed by HPLC for microalgal pigments according to Klein \& Sournia (1987). Pigment peaks were identified by comparison to chromatograms in Klein \& Sournia (1987) and to chromatograms of cultured microalgae.

Phytoplankton chl a was measured in the same water samples collected for primary productio measurements according to the standard fluorometric technique (Parsons et al. 1984). Triplicate $100 \mathrm{ml}$ samples were filtered through ashed Gelman A/E glass fiber filters and stored at $-4{ }^{\circ} \mathrm{C}$ prior to extraction for $24 \mathrm{~h}$ in $90 \%$ acetone and measurement of fluorescence on a Turner Model 111 filter fluorometer fitted with Corning 5-60 excitation and 2-64 emission filters. The fluorometer was calibrated with chl a extracts from cultured coastal phytoplankton using the spectrophotometric SCOR-UNESCO method (Parsons et al. 1984).

Primary production by phytoplankton was measured concurrently with benthic microalgal production using the ${ }^{14} \mathrm{C}$ light/dark bottle method (Parsons et al. 1984). Seawater was collected at the surface, middle, and bottom of each water column with a Niskin bottle. One set of 3 clear and 2 opaque (foil-wrapped) $250 \mathrm{ml}$ bottles was filled with water from each depth, inoculated with a ${ }^{14} \mathrm{C}$-labeled bicarbonate solution (1 to $2 \mu \mathrm{Ci}$ total activity), wrapped in screening to simulate light fluxes of $60 \%, 19 \%$, and $1.3 \%$ of surface incident radiation (corresponding to light fluxes at each specific sampling depth, respectively), and placed in a water-filled deck incubator stirred by the ship's motion for a 6 to $8 \mathrm{~h}$ period spanning mid-day concurrent with the benthic chamber incubations. Radiocarbon uptake was measured and production calculated as by Cahoon \& Cooke (1992). Average phytoplankton production values from the light treatments corresponding to different depths were multiplied by total depth to calculate total water column production. Phytoplankton production measured in this way is probably intermediate between gross and net production, owing to respiration and excretion of radiolabeled compounds during the incubations.

Photosynthetic photon flux density (PPFD) to the bottom was measured during each benthic production incubation. Two LiCor LI-193S spherical quantum sensors interfaced with a LiCor LI-1000 DataLogger were used for these measurements, allowing simultaneous measurement of surface- and bottom-incident PPFD.

\section{RESULTS}

Benthic microalgal chl a exceeded integrated phytoplankton chl a 6 of 7 times at Stellwagen Bank (Table 1). Divers observed a brown film on the surface of the sediments at each study site that made the top 1 to $3 \mathrm{~mm}$ of sediment more resistant to mechanical perturbation than the underlying sediment. HPLC analyses of sediment samples showed the presence of fucoxanthin, chl $c$, and chl $a$, characteristic of diatoms (Fig. 2). The lack of pigment markers for other taxa, e.g. zeaxanthin from cyanobacteria, suggested dominance of the benthic microflora by diatoms. Microscopic examination of surface sediment samples showed that the benthic microalgae were dominated by pennate diatoms (>97\% of total cells), including various Nitzschia spp., Navicula spp., and Amphora spp. (Beretich 1992).

Phytoplankton production was quite high at Stell-

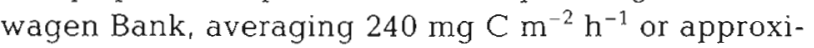
mately $2.9 \mathrm{~g} \mathrm{C} \mathrm{m}^{-2} \mathrm{~d}^{-1}$ assuming a $12 \mathrm{~h}$ production day (Table 2). This production value is probably intermediate between net and gross production, owing to cellular respiration and excretion of labeled compounds during the incubations. Phytoplankton production was consistently highest at the surface and was more than an order of magnitude greater at the surface than at the bottom.

Net benthic production was always negative at the Stellwagen Bank study sites on both an hourly and daily basis (Táble 3). Respiration values averaged $22.9 \pm 6.5 \mathrm{mg} \mathrm{C} \mathrm{m}{ }^{-2} \mathrm{~h}^{-1}$, or approximately $550 \mathrm{mg} \mathrm{C}$ $\mathrm{m}^{-2}$ per $24 \mathrm{~h}$ day. Gross benthic production averaged $15.9 \mathrm{mg} \mathrm{C} \mathrm{m}{ }^{-2} \mathrm{~h}^{-1}$, or approximately $190 \mathrm{mg} \mathrm{C} \mathrm{m}^{-2}$ for a $12 \mathrm{~h}$ production day (Table 3 ). Only one benthic microalgal gross production value (Site 3, 7 Aug 1991) 
Table 1. Comparison of phytoplankton and benthic microalgal chlorophyll a at study sites at Stellwagen Bank, Massachusetts Bay, in August 1991. Data are means $\pm 1 \mathrm{SD}_{i} \mathrm{n}=3$ for phytoplankton, $\mathrm{n}=5$ for benthic microalgae

\begin{tabular}{|c|c|c|c|c|c|}
\hline Site & Date & $\begin{array}{l}\text { Depth } \\
\text { (m) }\end{array}$ & $\begin{array}{r}\text { Phy } \\
\left(\mathrm{mg} \mathrm{m}^{-3}\right)\end{array}$ & $\left(\mathrm{mg} \mathrm{m}^{-2}\right)$ & $\begin{array}{l}\text { Benthic microalgae } \\
\qquad\left(\mathrm{mg} \mathrm{m}^{-2}\right)\end{array}$ \\
\hline 1 & 1 Aug 1991 & $\begin{array}{r}0 \\
10 \\
21\end{array}$ & $\begin{array}{l}0.32 \pm 0.05 \\
1.77 \pm 0.11 \\
0.69 \pm 0.07\end{array}$ & 24.4 & $79.4 \pm 27.8$ \\
\hline 1 & 2 Aug 1991 & $\begin{array}{r}0 \\
10 \\
21\end{array}$ & $\begin{array}{l}0.44 \pm 0.06 \\
3.52 \pm 0.25 \\
0.94 \pm 0.08\end{array}$ & 43.7 & $49.0 \pm 28.1$ \\
\hline 1 & 3 Aug 1991 & $\begin{array}{r}0 \\
10 \\
21\end{array}$ & $\begin{array}{l}0.70 \pm 0.06 \\
1.96 \pm 0.19 \\
0.61 \pm 0.06\end{array}$ & 29.5 & $53.7 \pm 21.2$ \\
\hline 2 & 4 Aug 1991 & $\begin{array}{r}0 \\
15 \\
27\end{array}$ & $\begin{array}{l}1.13 \pm 0.20 \\
1.03 \pm 0.11 \\
0.90 \pm 0.10\end{array}$ & 28.5 & $15.8 \pm 5.7$ \\
\hline 2 & 5 Aug 1991 & $\begin{array}{r}0 \\
15 \\
27\end{array}$ & $\begin{array}{l}0.84 \pm 0.06 \\
0.74 \pm 0.05 \\
0.69 \pm 0.07\end{array}$ & 21.4 & $27.4 \pm 12.0$ \\
\hline 3 & 6 Aug 1991 & $\begin{array}{r}0 \\
15 \\
27\end{array}$ & $\begin{array}{l}0.44 \pm 0.03 \\
1.09 \pm 0.06 \\
0.29 \pm 0.06\end{array}$ & 20.6 & $47.9 \pm 9.4$ \\
\hline 3 & 7 Aug 1991 & $\begin{array}{r}0 \\
15 \\
27\end{array}$ & $\begin{array}{l}0.29 \pm 0.09 \\
0.66 \pm 0.03 \\
0.39 \pm 0.05\end{array}$ & 13.3 & $59.5 \pm 19.2$ \\
\hline
\end{tabular}

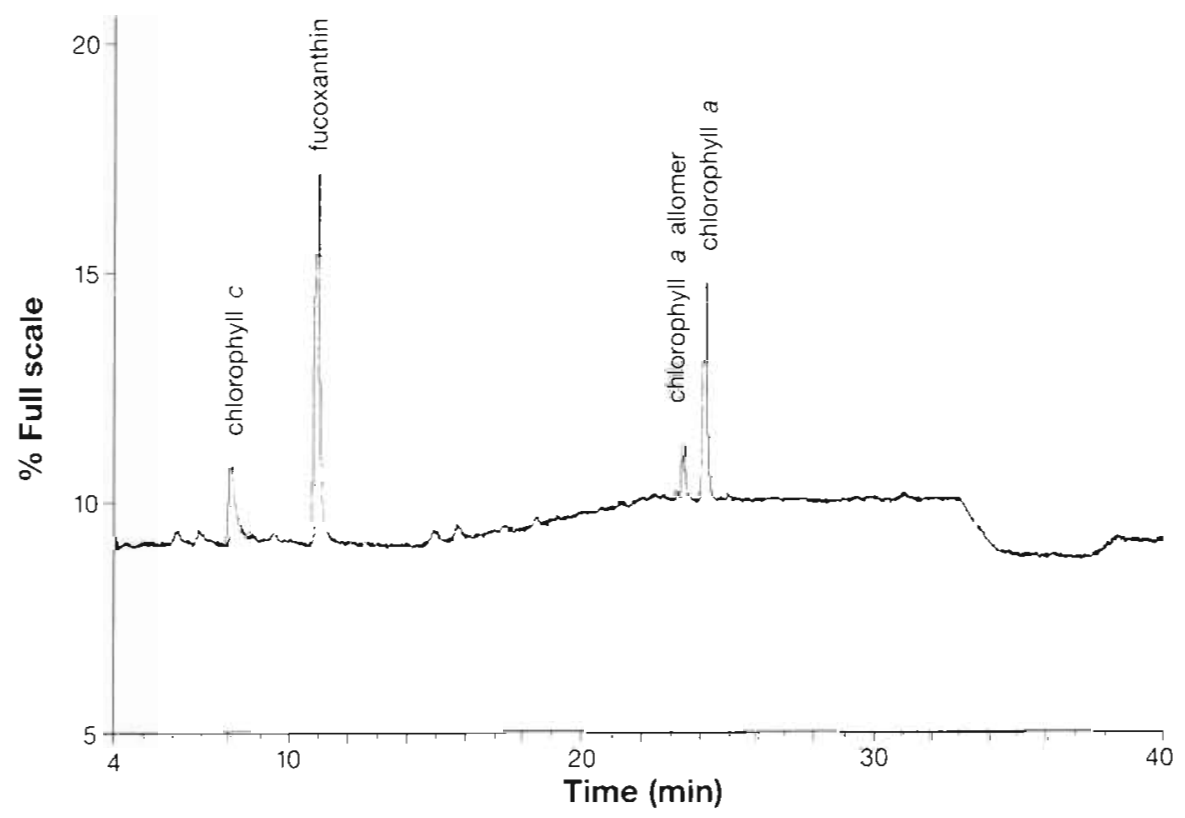

Fig. 2. HPLC chromatogram of sediment pigment extracts from Site 2 at Stellwagen Bank (Fig. 1), 3 Aug 1991, analyzed according to Klein \& Sournia (1987) 
Table 2. Primary production by phytoplankton at 3 study sites at Stellwagen Bank, Massachusetts Bay, in August 1991. Production data are means of 3 replicates

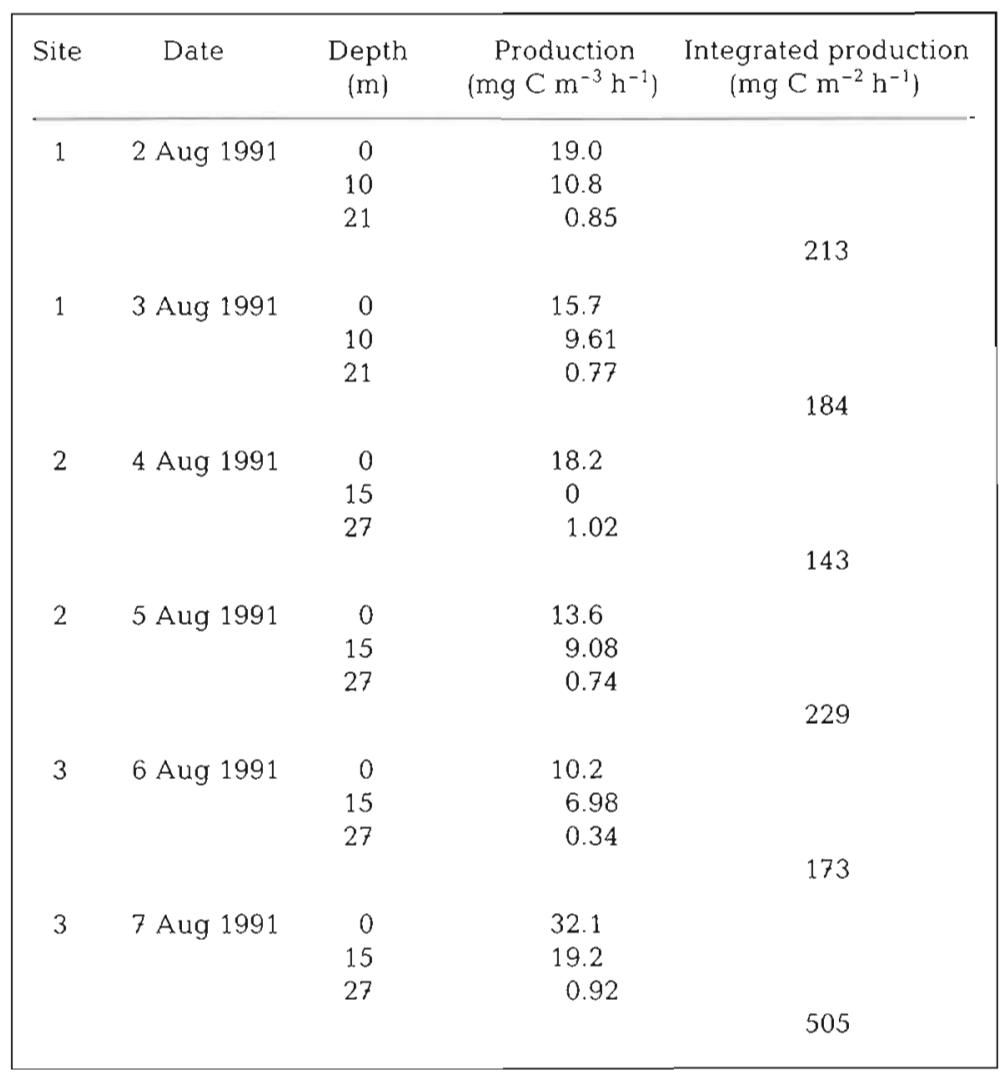

Benthic microalgal production was supported by PPFD values always less than $1 \%$ of surface incident PPFD (Table 3 ). Average integrated PPFD at the bottom for 5 measurements was $11.3 \mu \mathrm{mol} \mathrm{m} \mathrm{m}^{-2} \mathrm{~s}^{-1}$ or $0.52 \%$ of surface incident radiation. Measurable production was supported by average PPFD values as low as $4.7 \mu \mathrm{mol}$ $\mathrm{m}^{-2} \mathrm{~s}^{-1}$

\section{DISCUSSION}

Comparatively few studies have examined benthic microalgal production in offshore habitats, although many studies have reported benthic microalgal production in intertidal and shallow, subtidal, nearshore habitats (e.g. Colijn \& de Jonge 1984, Varela $\&$ Penas 1985). Some studies have reported significant benthic microalgal production from deeper subtidal habitats but at relatively high bottom-incident PPFD levels (e.g. Sournia 1976, Cahoon \& Cooke 1992). Although some studies suggest that benthic microalgae can photosynthesize at PPFDs as low as ca $1 \mu \mathrm{mol} \mathrm{m} \mathrm{m}^{-2} \mathrm{~s}^{-1}$ (e.g Palmisano et al. 1985, 1987, Rivkin \& DeLaca 1990), others have shown benthic microalgal production to be low and light limited at PPFD levels below $30 \mu \mathrm{mol}$ $\mathrm{m}^{-2} \mathrm{~s}^{-1}$ (Sundbäck \& Jönsson 1988). Consequently the results of previous studies did not predict the widespread distribution of productive benthic microflora in continental shelf habitats.

Net benthic production at Stellwagen Bank was a relatively small fraction (ca $6 \%$ ) of total water column production and was consistently negative. However, phytoplankton production at Stellwagen Bank is was not statistically different from zero owing to high variance in both net production and respiration values, probably because of patchiness at Site 3. Average gross benthic production was approximately $6 \%$ of average integrated phytoplankton production, but an accurate comparison of true net production by phytoplankton and benthic microalgae would probably yield a somewhat different value.

Table 3. Net benthic production (NETBP), benthic respiration (RESP), and gross benthic production (GROSS) (mg C $\left.\mathrm{m}^{-2} \mathrm{~h}^{-1}\right)$ at Stellwagen Bank sites in August 1991. Data are means $\pm 1 \mathrm{SD}$. Temp. = bottom temperature; $I_{b}=$ average integrated PPFD $\left(\mu \mathrm{mol} \mathrm{m} \mathrm{s}^{-1}\right)$ at the bottom during benthic incubations; $\% I_{0}=$ percent average surface incident PPFD represented by $I_{\mathrm{b}}$

\begin{tabular}{|c|c|c|c|c|c|c|c|c|}
\hline Date & Site & $\begin{array}{l}\text { Depth } \\
\text { (m) }\end{array}$ & $\begin{array}{c}\text { Temp. } \\
\left({ }^{\circ} \mathrm{C}\right)\end{array}$ & NETBP & RESP & GROSS & $I_{\mathrm{b}}$ & $\% I_{0}$ \\
\hline 1 Aug 1991 & 1 & 21.3 & 7.5 & $-5.49 \pm 3.9$ & $26.8 \pm 5.4$ & 21.3 & - & - \\
\hline 2 Aug 1991 & 1 & 20.7 & 7.9 & $-12.7 \pm 6.0$ & $28.0 \pm 5.8$ & 15.3 & 11.9 & 0.53 \\
\hline 3 Aug 1991 & 1 & 21.0 & 6.5 & $-16.2 \pm 6.7$ & $30.6 \pm 7.9$ & 14.4 & 10.8 & 0.76 \\
\hline 4 Aug 1991 & 2 & 27.7 & 7.4 & $-11.5 \pm 5.0$ & $21.7 \pm 5.2$ & 10.2 & 4.7 & 0.28 \\
\hline 5 Aug 1991 & 2 & 28.3 & 6.9 & $-3.46 \pm 4.3$ & $20.4 \pm 6.9$ & 17.9 & - & - \\
\hline 6 Aug 1991 & 3 & 28.3 & 6.0 & $-5.52 \pm 1.8$ & $11.0 \pm 0.8$ & 16.5 & 17.6 & 0.61 \\
\hline 7 Aug 1991 & 3 & 26.8 & 5.9 & $-6.27 \pm 17.8$ & $21.8 \pm 18.6$ & $15.5^{\mathrm{a}}$ & 11.7 & 0.43 \\
\hline
\end{tabular}


comparatively high (ca $2.9 \mathrm{~g} \mathrm{C} \mathrm{m}^{-2} \mathrm{~d}^{-1}$ ). Typical phytoplankton production rates in the mid-Atlantic Bight and the Gulf of Maine are ca $0.8 \mathrm{~g} \mathrm{C} \mathrm{m}^{-2} \mathrm{~d}^{-1}$ (Schlitz \& Cohen 1984, Walsh 1988) and ca $1.3 \mathrm{~g} \mathrm{C} \mathrm{m}^{-2} \mathrm{~d}^{-1}$ in shallow portions of Georges Bank (Schlitz \& Cohen 1984). Sediment respiration rates at Stellwagen Bank may have been stimulated by high loading of organic material, particularly via fecal pellets excreted by the abundant zooplankton population at Stellwagen Bank (ca $2.9 \times 10^{5}$ animals $\mathrm{m}^{-2}$; L. B. Cahoon et al. unpubl.). The contribution of benthic microalgal production in continental shelf habitats with less productive water column communities may be relatively greater than at Stellwagen Bank. Net benthic production has been found to be positive in other coastal habitats (e.g. Nowicki \& Nixon 1985, Anderson et al. 1986, Hofman et al. 1990, Cahoon \& Cooke 1992).

The importance of benthic microalgal production at Stellwagen Bank derives from the apparent ability of the distinctly benthic microalgal assemblage there to sustain significant production at light levels consistently below $1 \%$ surface incident PPFD. If this ability is common, benthic microalgae may be widely distributed in continental shelf habitats. Benthic habitats underlying clearer, less productive water columns than at Stellwagen Bank may support relatively higher benthic microalgal production. Benthic microalgal production may therefore be a significant, if infrequently considered, fraction of total production in continental shelf ecosystems.

Acknowledgements. This research was supported by the National Undersea Research Centers at the University of Connecticut-Avery Point (NOAA/NURP NA90AA-D-UR128: UCAT-91-02) and the University of North Carolina - Wilmington (NA88AA-D-URO04). Additional support was provided by the Duke-University of North Carolina Oceanographic Consortium and the Center for Marine Science Research at UNCW. We thank D. Kesling, R. DeGoursey, K. Johns, P. Hunter, and the crew of RV 'Seaward Explorer' for field support. This is CMSR Contribution no. 057.

\section{LITERATURE CITED}

Anderson, L. G., Hall, P. O. J., Iverfeldt, A., Rutgers van der Loeff, M., Sundby, B., Westerlund, S. F. G. (1986). Benthic respiration measured by total carbonate production. Limnol. Oceanogr. 31. 319-329

Beretich, G. R. Jr (1992). Comparisons of water column and benthic chlorophylls on the eastern U.S. continental shelf. M.S. thesis, Univ. of N. Carolina, Wilmington

Bunt, J. S., Lee, C. C., Lee, E. (1972). Primary productivity and related data from tropical and subtropical marine sediments. Mar. Biol. 16: 28-36

Cadee, G. C., Hegeman, J (1974). Primary production of the benthic microflora living on tidal flats in the Dutch Wadden See. Neth. J. Sea Res. 8: 260-291

Cahoon, L. B. (1988). The use of whirling cup rotors to stir benthic chambers. Hydrobiologia 160: 193-198
Cahoon, L. B., Cooke, J. E. (1992). Benthic microalgal production in Onslow Bay, North Carolina, USA. Mar. Ecol. Prog Ser. 84: 185-196

Cahoon, L. B., Laws, R. A., Savidge, T W. (1992). Characteristics of benthic microalgae from the North Carolina outer continental shelf and slope: preliminary results. In: Cahoon, L. B. (ed.) Diving for science....1992. American Academy of Underwater Sciences, Costa Mesa, CA, p. 61-68

Cahoon, L. B., Redman, R. S., Tronzo, C. R. (1990). Benthic microalgal biomass in sediments of Onslow Bay, North Carolina. Estuar. coast. Shelf Sci. 31: 805-816

Colijn, F., de Jonge, V. N. (1984). Primary production of microphytobenthos in the Ems-Dollard estuary. Mar. Ecol. Prog. Ser. 14: 185-196

Herndl, G. J., Peduzzi, P., Fanuko, N. (1989). Benthic community metabolism and microbial dynamics in the Gulf of Trieste (Northern Adriatic Sea). Mar. Ecol. Prog. Ser. 53: $169-178$

Hofman, P. A. G., De Jong, S. A., Wagenvoort, E. J., Sandee, A. J. J. (1991). Apparent sediment diffusion coefficients for oxygen and oxygen consumption rates measured with microelectrodes and bell jars: application to oxygen budgets in estuarine intertidal sediments (Oosterschelde, SW Netherlands). Mar. Ecol. Prog. Ser. 69: 261-272

Holligan, P. M., Balch, W. M., Yentsch, C. M. (1984). The significance of subsurface chlorophyll, nitrite, and ammonium maxima in relation to nitrogen for phytoplankton growth in stratified waters of the Gulf of Maine. J. mar. Res. 42: 1051-1073

Klein, B., Sournia, A. (1987). A daily study of the diatom spring bloom at Roscoff (France) in 1985. I. Phytoplankton pigment composition studied by HPLC analysis. Mar. Ecol. Prog. Ser. 37: 265-275

Lukatelich, R. J., McComb, A. J. (1986). Distribution and abundance of benthic microalgae in a shallow southwestern Australian estuarine system. Mar. Ecol. Prog. Ser 27: $287-297$

Matheke, G. E. M., Horner, R. (1974). Primary productivity of the benthic microalgae in the Chukchi Sea near Barrow Alaska. J. Fish. Res. Bd Can. 31: 1779-1786

National Oceanographic Data Center (NODC) (1987). Worldwide ocean water color/water transparency data. National Environmental Satellite, Data, and Information Service, National Oceanographic Data Center, Washington, DC 20235

Nowicki, B. L., Nixon, S. W. (1985). Benthic community metabolism in a coastal lagoon ecosystem. Estuaries 8: 182-190

Palmisano, A. C., SooHoo, J., Sullivan, C. (1987). Effects of four environmental variables on photosynthesis-irradiance relationships in Antarctic sea-ice microalgae. Mar. Biol. 94 299-306

Palmisano, A. C., SooHoo, J. B., White, D. C., Smith, G. A., Stanton, G. R., Burckle, L. H. (1985). Shade adapted benthic diatoms beneath Antarctic sea ice. J. Phycol. 21: $664-667$

Pamatmat, M. M. (1968). Ecology and metabolism of a benthic community on an intertidal sand flat. Int. Rev. ges. Hydrobiol. 53: 211-298

Parsons, T R. Maita, Y., Lalli, C. M. (1984). A manual of chemical and biological methods for seawater analysis. Pergamon Press, New York

Rivkin, R. B., DeLaca, T E. (1990). Trophic dynamics in Antarctic benthic communities. I. In situ ingestion of microalgae by Foraminifera and metazoan meiofauna. Mar. Ecol. Prog. Ser. 64: 129-136

Schlitz, R. J., Cohen, E. B. (1984). A nitrogen budget for the Gulf of Maine and Georges Bank. Oceanography 3: 203-222 
Sournia, A. (1976). Primary production of sands in the lagoon of an atoll, and the role of foraminiferan symbionts. Mar. Biol. 37: 29-32

Strickland, J. D. H., Parsons, T R. (1972). A practical handbook of seawater analysis. Bull. Fish. Res. Bd Can. 167

Sundbäck, K., Jönsson, B. (1988). Microphytobenthic productivity and biomass in sublittoral sediments of a stratified bay, southeastern Kattegat. J. exp. mar. Biol. Ecol. 122: $63-81$

Vadas, R. L., Steneck, R. S. (1988). Zonation of deep water benthic algae in the Gulf of Maine. J. Phycol. 24: 338-346

Varela, M., Penas, E. (1985). Primary production of benthic

This article was submitted to the editor microalgae in an intertidal sand flat of the Ria de Arosa, NW Spain. Mar. Ecol. Prog. Ser. 25: 111-119

Walsh, J. J. (1988). On the nature of continental shelves Academic Press, New York

Whitney, D. E., Darley, W. M. (1979). A method for the determination of chlorophyll $a$ in samples containing degradation products. Limnol. Oceanogr. 24: 183-186

Yentsch, C. M., Garfield, N. (1981). Principal areas of vertical mixing in the waters of the Gulf of Maine, with reference to total productivity of the area. In: Gower, J. F. R. (ed.) Oceanography from space. Plenum Press, New York, p. $303-312$

Manuscript first received: May 21, 1993

Revised version accepted: July 29, 1993 